\title{
40 Years Ago
}

\section{Statistical analysis of $\mathbf{7 5 0}$ cleft lip and palate patients}

\author{
San D. Theogaraj, LBM Joseph. Mani M \\ Christian Medical College and Hospital, Vellore, India
}

\section{INTRODUCTION}

he period under study is from January, 1959-June, 1967 and 750 consecutive patients have been analysed.

In an earlier analysis, we presented 492 cases in 1964, utilizing the classification of Davis and Ritchie. ${ }^{[1]}$ In this paper we have favoured the Harkins et al classification, ${ }^{[2]}$ since it is based on more sound embryological principles.

\section{INCIDENCE [TABLE 1]}

From 1959-1967, we have had 645,197 new out-patients and 750 of these have been patients with cleft lip and/or palate. This is an incidence of $1: 860$. Of course, this is by no means the absolute incidence in the general population, but only an indication of its relative frequency.

During this period we have had 13,821 live births in our hospital and of these there were 26 cases of cleft lip and/or palate; an incidence of 1:532 live births. Oldfield, ${ }^{[3]}$ found an incidence of 1:600 live births.

\section{CLEFT TYPE [TABLE 2]}

Prepalatal clefts, in the Harkins classification, are those that involve the region anterior to the naso-palatine foramen. These clefts occur between the $4^{\text {th }}-7^{\text {th }}$ week and are due to

Table 1: Incidence In C, M. C. H. (1959-1967)
New patients with $C L$ and/or $P$

750

INCIDENCE IS 1: 860

Live births with $C \mathrm{~L}$ and/or $P$

26
INCIDENCE IS $1 ; 532$
New O.P.D. patients

645,197

Total no, of live births 13,821 lack of mesodermal penetration. ${ }^{[4]}$

Palatal clefts are those that are posterior to the naso-palatine foramen. These become cleft due to failure of fusion of the two shelves and this takes place between the 7 th $-12^{\text {th }}$ week. The Davis and Ritchie ${ }^{[1]}$ classification lays stress on the alveolus and divides clefts into pre-alveolar, post-alveolar, etc. Since the dividing zone ought to be the foramen and not the alveolus, we have elected to use the Harkins classification, throughout.

In all of the studies including our own, clefts of the prepalate and palate ( 2 and 3 ) rank the highest. In our series and in that of Keys Smith, prepalatal clefts are next in frequency and isolated clefts of the palate the least. This is exactly reversed in the Caucasian series.

This difference may be an artificial one. Parents in the East are more likely to bring a child with a cleft lip to the hospital, than if it were to have an isolated cleft of the palate, because this would not be obvious to the casual observer and also would not serve to remind the parents of the defect everyday. When the child begins to talk, however, the defect becomes revealed and the children then tend to be brought for treatment. This statement is borne out by scrutinizing the analysis of the age at First Visit to Hospital [Table 3].

Most children with clefts of the prepalate with or without palate involvement are brought to hospital before their first year. Clefts of the palate alone, are brought in much later.

\section{SEX DISTRIBUTION [TABLE 4]}

The male: female ratio is $4: 3$. A male preponderance for clefts has been observed in all major series of patients.

Clefts of the palate alone are more common in females F: M 
Table 2: Cleft types

\begin{tabular}{|c|c|c|c|c|c|c|c|}
\hline $\begin{array}{l}\text { Type of } \\
\text { (Denmark) }\end{array}$ & $\begin{array}{c}\text { Fogh-Andersen } \\
1942 \\
\text { (Leeds) }\end{array}$ & $\begin{array}{c}\text { Oldfield } \\
1959 \\
1960\end{array}$ & $\begin{array}{c}\text { Rank and } \\
\text { Thomson } \\
1961 \\
\text { (Tasmania) }\end{array}$ & $\begin{array}{l}\text { Fraser and } \\
\text { Calnan } \\
1963 \\
\text { (Oxford) }\end{array}$ & $\begin{array}{l}\text { Woolf } \\
\text { et al. } \\
1962 \\
\text { (Utah) }\end{array}$ & $\begin{array}{c}\text { Keys } \\
\text { Smith } \\
1967 \\
\text { (Singapore) }\end{array}$ & $\begin{array}{l}\text { C. M. C. } \\
\text { Hospital Cleft } \\
\text { (Vellore) }\end{array}$ \\
\hline 1. Prepalate only & $138(19.6 \%)$ & $233(22.4 \%)$ & $50(22.6 \%)$ & $93(20.4 \%)$ & $128(23.1 \%)$ & $90(25.1 \%)$ & $216(28.8 \%)$ \\
\hline $\begin{array}{l}2 \text { and } 3 \text {. Prepalate } \\
\text { and palate }\end{array}$ & $360(51.2 \%)$ & $450(43.2 \%)$ & $97(43.9 \%)$ & $152(33.3 \%)$ & $290(52.5 \%)$ & $224(62.4 \%)$ & 428 (56.9\%) \\
\hline 4. Palate only & $205(29.2 \%)$ & $358(34.4 \%)$ & $74(33.5 \%)$ & $211(46.3 \%)$ & $135(24.4 \%)$ & $45(12.5 \%)$ & $106(14.3 \%)$ \\
\hline
\end{tabular}

Table 3: Age at first visit to hospital (1959-1967)

\begin{tabular}{|c|c|c|c|c|c|c|c|c|c|c|}
\hline Type of Cleft & $\begin{array}{l}0-30 \\
\text { Days }\end{array}$ & $\begin{array}{l}1 \mathrm{mth} . \\
-1 \mathrm{Yr} .\end{array}$ & $\begin{array}{l}1-2 \\
\text { Yrs. }\end{array}$ & $\begin{array}{l}2-3 \\
\text { Yrs. }\end{array}$ & $\begin{array}{l}3-4 \\
\text { Yrs. }\end{array}$ & $\begin{array}{l}4-5 \\
\text { Yrs. }\end{array}$ & $\begin{array}{l}5-9 \\
\text { Yrs. }\end{array}$ & $\begin{array}{l}9-14 \\
\text { Yrs. }\end{array}$ & $\begin{array}{c}\text { Above } 14 \\
\text { Yrs. }\end{array}$ & Total \\
\hline Prepalate only & 1 & 85 & 21 & 15 & 9 & 8 & 28 & 16 & 33 & 216 \\
\hline $\begin{array}{l}\text { Prepalate and palate } \\
\text { (complete) }\end{array}$ & 12 & 132 & 67 & 37 & 26 & 14 & 50 & 35 & 35 & 408 \\
\hline $\begin{array}{l}\text { Prepalate and palate } \\
\text { (incomplete) }\end{array}$ & 0 & 3 & 6 & 1 & 2 & 0 & 3 & 1 & 4 & 20 \\
\hline Palate only & 3 & 11 & 13 & 17 & 12 & 12 & 18 & 8 & 12 & 106 \\
\hline Total & 16 & 231 & 107 & 70 & 49 & 34 & 99 & 60 & 84 & 750 \\
\hline
\end{tabular}

(6: 4). The ratio is exactly reversed in clefts of the prepalate with or without palate involvement, M: F 6: 4.

\section{FAMILY HISTORY [TABLE 5]}

The overall incidence of clefts in families is $12.1 \%$. Oldfield found a $12.5 \%$ family history in a study of 1,041 patients.

\section{OTHER CONGENITAL ANOMALIES}

They were found in 60 cases. There were 63 anomalies in all. Isolated clefts of the palate had a higher incidence than the other varieties. Drillien et al., ${ }^{[8]}$ came to a similar conclusion in their Edinburgh study.

\section{CLEFTS OF THE PREPALATE [TABLE 6]}

Left sided clefts occurred in half of all prepalatal clefts. Right sided and bilateral clefts constituted 25\% each. Complete clefts by far outnumbered the incomplete. Fogh

Table 4 (a): Sex incidence

\begin{tabular}{lcc}
\hline Males & Females $^{\prime}$ & Total \\
419 & 331 & 750 \\
Cases & Cases & Cases \\
\hline
\end{tabular}

Andersen ${ }^{[6]}$ had $64 \%$ left sided clefts in his series, Rank and Thomson ${ }^{[7]} 68 \%$ and Fraser and Calnan ${ }^{[9]} 51.6 \%$. The preponderance of left sided clefts of the pre palate seems therefore to be a universal finding.

\section{CLEFTS OF THE PALATE [TABLE 7]}

In order to compare our series with that of others, we have simultaneously classified cleft palates, according to the Veau (1931) classification.

The figures in our series and in that of Keys Smith's, ${ }^{[10]}$ are almost identical. More severe clefts, tend to be brought to hospital more often, in our part of the world.

Table 5: Family history and other congenital anomalies

\begin{tabular}{|c|c|c|c|}
\hline Type of cleft & $\begin{array}{l}\text { Family } \\
\text { history }\end{array}$ & $\begin{array}{c}\text { Other } \\
\text { congenital } \\
\text { anomalies }\end{array}$ & Total \\
\hline Prepalate only & $20(8.3 \%)$ & $11(5.1 \%)$ & 216 \\
\hline $\begin{array}{l}\text { Prepalate and } \\
\text { palate (Complete) }\end{array}$ & $53(13.0 \%)$ & $33(8.1 \%)$ & 408 \\
\hline $\begin{array}{l}\text { Prepalate and } \\
\text { palate (Incomplete) }\end{array}$ & $2(8.7 \%)$ & $1(4.3 \%)$ & 20 \\
\hline Palate only & $16(15.0 \%)$ & $15(14.1 \%)$ & 106 \\
\hline Total & $91(121 \%)$ & $60(8.0 \%)$ & 750 \\
\hline
\end{tabular}

Table 4 (b): Sex Distribution

\begin{tabular}{|c|c|c|c|c|c|c|c|c|}
\hline \multirow[t]{2}{*}{ Type of Cleft } & \multicolumn{2}{|c|}{$\begin{array}{l}\text { Macmahon and } \\
\text { Mckeown } 1953^{[5]}\end{array}$} & \multicolumn{2}{|c|}{$\begin{array}{c}\text { Fogh Andersen } \\
1942^{[6]}\end{array}$} & \multicolumn{2}{|c|}{$\begin{array}{c}\text { Rank and Thomson } \\
1960^{[7]}\end{array}$} & \multicolumn{2}{|c|}{$\begin{array}{l}\text { C. M. C. H. } \\
\text { Series } 1967\end{array}$} \\
\hline & $M$ & $F$ & $M$ & $F$ & $M$ & $F$ & $M$ & $F$ \\
\hline 1 Prepalate only & $60.6 \%$ & & $65.2 \%$ & & $64.0 \%$ & & $54.6 \%$ & \\
\hline 2 and 3. Prepalate and palate & $59.0 \%$ & & $71.4 \%$ & & $76.3 \%$ & & $600 \%$ & \\
\hline 4. Palate only & & $28.8 \%$ & & $64.9 \%$ & & $56.8 \%$ & & $61.3 \%$ \\
\hline
\end{tabular}




\section{DISTRIBUTION STATEWISE [TABLE 8]}

As is to be expected, the majority of patients that attend our hospital, come from our own state. The rest are mainly from the neighbouring regions. More detailed analysis of the 250 cases (1965-1967).

\section{CONSANGUINITY [TABLE 9]}

One hundered and thirty five out of 250 cases had parents that were very closely related to each other. The prevalent custom in our part of the country, however, is towards an uncle-niece or 1st cousin marriage. It is difficult, therefore, to assess how much weight ought to be given this finding.

\section{AGE AT CONCEPTION [TABLE 10]}

Majority of the mothers conceived between 15 -30 years of age $(86.0 \%)$. Loretz et al. ${ }^{[11]}$ in a study from California, found 13;0 of mothers of affected children between 30-40 years of age, as compared with less than $10 \%_{\circledast}$ of mothers of all infants. We also have $13 \%$ of mothers in the same age group, but have no figures as yet for the general population.

\section{BIRTH RANK [TABLE 11]}

Malpas ${ }^{[12]}$ and Murphy, ${ }^{[13]}$ were of the opinion that maternal age over 40 years and later parities predisposed to the birth of children with clefts. Oldfield, ${ }^{[3]} \mathrm{Knox}^{[14]}$ and others have not found this to be so. Our findings are similar to the latter group of workers. More than half of our patients fall within the 1 st two birth ranks.

\section{ADVERSE ENVIRONMENTAL FACTORS [TABLE 12]}

Diseases and other noxious influences during the $1^{\text {st }}$ trimester were found in only $6 \%$ of cases. In $a$ retrospective study, one is hard put to attach too much significance to this, especially when numbers are so few and a comparable history from mothers of normal infants is lacking. Detailed questioning, for all possible teratogenic influences operating in the 1 st trimester, was undertaken in the last 250 cases, but the response from the informants was far from satisfactory.

Frank middle ear disease has been detected in only 14 cases [Table 13]. There was sensory neural loss in one case. This gives a percentage of $9 \%$ of 172 cases, with hearing loss. Peer

Table 6: Clefts of the prepalate

\begin{tabular}{|c|c|c|c|c|c|}
\hline \multicolumn{2}{|c|}{ Left } & \multicolumn{2}{|c|}{ Right } & \multirow[t]{2}{*}{ Bilateral } & \multirow[t]{2}{*}{ Total } \\
\hline Incomplete & Complete & Incomplete & Complete & & \\
\hline 58 & 267 & 41 & 114 & 164 & 644 \\
\hline$(9.0 \%)$ & $(41.5 \%)$ & $(6.4 \%)$ & $(17.7 \%)$ & $(25.4 \%)$ & $(100 \%)$ \\
\hline & & \multicolumn{2}{|c|}{$24.1 \%$} & $25.4 \%$ & $100 \%$ \\
\hline
\end{tabular}

Table 7: Clefts of the Palate

\begin{tabular}{|c|c|c|c|c|}
\hline $\begin{array}{l}\text { Veau } \\
\text { Types }\end{array}$ & $\begin{array}{l}\text { Veau } \\
1931\end{array}$ & $\begin{array}{l}\text { Oldfield } \\
1949^{[3]}\end{array}$ & $\begin{array}{c}\text { Keys Smith } \\
1962^{[10]}\end{array}$ & $\begin{array}{r}\text { C.M.C.H } \\
\text { series } 1967\end{array}$ \\
\hline $\begin{array}{l}\text { Types } \\
\text { I and II }\end{array}$ & $516(51.6 \%)$ & $190(46.0 \%)$ & $60(22.3 \%)$ & $126(23.6 \%)$ \\
\hline $\begin{array}{l}\text { Types } \\
\text { III and IV }\end{array}$ & $484(484 \%)$ & $222(54.0 \%)$ & $209(77.7 \%)$ & $408(76.4 \%)$ \\
\hline Total & $\begin{array}{c}1000 \\
(100.0 \%)\end{array}$ & $\begin{array}{c}412 \\
(100.0 \%)\end{array}$ & $\begin{array}{c}269 \\
(100.0 \%)\end{array}$ & $\begin{array}{c}534 \\
(100.0 \%)\end{array}$ \\
\hline
\end{tabular}

Table 8: Statewise Distribution

\begin{tabular}{|c|c|c|c|c|c|}
\hline Tpye of cleft & Tamilnad & Kerala & $\begin{array}{l}\text { Andhra } \\
\text { Pradesh }\end{array}$ & Mysore & Others \\
\hline Prepalate only & 149 & 19 & 32 & 11 & 5 \\
\hline $\begin{array}{l}\text { Prepalate and } \\
\text { palate (complete) }\end{array}$ & 224 & 61 & 64 & 37 & 22 \\
\hline $\begin{array}{l}\text { Prepalate and } \\
\text { palate } \\
\text { (incomplete) }\end{array}$ & 15 & 1 & 4 & 0 & 0 \\
\hline Palate only & 65 & 22 & 12 & 4 & 3 \\
\hline Total & 453 & 103 & 112 & 52 & 30 \\
\hline
\end{tabular}

Table 9: Consanguinity

\begin{tabular}{lc} 
Relationship & Number of cases \\
Uncle-Niece & 60 \\
First cousins & 42 \\
Other & 33 \\
Total & 135 \\
Not related & 115 \\
Total & 250 \\
\hline
\end{tabular}

Table 10: Age of mother

$\begin{array}{lc}\text { Age at Conception } & \text { Number of cases } \\ \text { Below } 14 \text { years } & 2(1.1 \%) \\ 15-20 \text { years } & 51(29.6 \%) \\ 20-30 \text { years } & 97(56.4 \%) \\ 30-40 \text { years } & 22(12.9 \%) \\ \text { Over } 40 \text { years } & 0 \\ \text { Total } & 172 \\ \text { Not known } & 78 \\ \text { Total } & 250\end{array}$


Table 11: Birth rank

\begin{tabular}{|c|c|c|c|c|c|c|c|c|c|c|c|c|}
\hline \multirow[b]{2}{*}{ Type of Cleft } & \multicolumn{12}{|c|}{ Parity } \\
\hline & 1 & 2 & 3 & 4 & 5 & 6 & 7 & 8 & 9 & 10 & Not known & Total \\
\hline Prepalate only & 22 & 14 & 11 & 13 & 9 & 3 & - & 1 & 1 & 1 & 3 & 78 \\
\hline Prepalate and & 35 & 40 & 14 & 14 & 5 & 5 & 3 & 2 & 1 & - & 7 & 126 \\
\hline Palate (Complete) & & & & & & & & & & & & \\
\hline $\begin{array}{l}\text { Prepalate and } \\
\text { palate (Incomplete) }\end{array}$ & 2 & 1 & 3 & 2 & 1 & - & - & - & - & - & 1 & 10 \\
\hline Palate only & 11 & 6 & 6 & 5 & 2 & 2 & 1 & - & 2 & - & 1 & 36 \\
\hline Total & 70 & 61 & 34 & 34 & 17 & 10 & 4 & 3 & 4 & 1 & 12 & 250 \\
\hline
\end{tabular}

Table 12: Adverse environmental factors

\begin{tabular}{|c|c|c|c|c|c|c|}
\hline Type of cleft & & Dis & & & Total & \\
\hline Prepalate only & Hyperemesis & & Malaria? & & 2 & $2.5 \%$ of 78 cases \\
\hline $\begin{array}{l}\text { Prepalate and palate } \\
\text { (complete) }\end{array}$ & 2 & Viral infect 5 & 1 & Asthma 2 & 10 & $8.0 \%$ of 126 cases \\
\hline $\begin{array}{l}\text { Prepalate and palate } \\
\text { (incomplete) }\end{array}$ & & $\mathrm{N}$ & I & L & & \\
\hline Palate only & & $\mathrm{N}$ & I & L & & \\
\hline
\end{tabular}

Table 13: Incidence of deafness

\begin{tabular}{lcccc}
\hline Type of cleft & Otitis Media & $\begin{array}{c}\text { Sensory } \\
\text { neural loss }\end{array}$ & Otosclerosis \\
Prepalate only & & 1 & 1 & \\
Prepalate and palate & 4 & 6 & & 1 \\
Palate only & 1 & 1 & 1 & 1 \\
Total & 5 & 8 & \\
\hline
\end{tabular}

et $\mathrm{al}^{[15]}$ detected $60 \%$ and Masters et al. $^{[16]} 50 \%$ of children with cleft palates, to be afflieted with significant hearing loss. Routine E.N.T. examinations have been conducted in all our cases, but audiograms have been done only when felt indicated and hence, our low figures. Recently, Stool and Randall[17] reported on middle ear pathology in 94\% of cases with clefts, when routine myringotomies were performed.

Since the physiology of the Eustachian tubes is interfered with when a cleft is unrepaired, the onset of middle ear disease is not surprising. The longer after 18 months a cleft of the palate is unrepaired, the higher the incidence. All of our affected cases had repairs after 18 months and the more severe the cleft, the greater the number of cases with middle ear diseases. Masters ${ }^{[16]}$ was of a like opinion.

\section{SUMMARY}

1. 750 cleft lip and palate cases have been analysed.

2. Clefts which involve the prepalate and palate proper, are seen most commonly.

3. M.F. ratio is $4: 3$.

4. There is a positive family history in $12.1 \%$.

5. Left sided clefts of the prepalate are found in $50 \%$ of cases.
6. There was a history of consanguinity in over $50 \%$ of 250 cases.

7. Maternal age and birth rank are not of much significance.

8. Middle ear disease was found in only $9 \%$ of cases and the reason for this is offered.

\section{REFERENCES}

1. Davis JS, Ritchie HP. Classification of congenital clefts of lip and palate. J Am Med Assoc 1922;79:1323.

2. Harkin CS, Berlin A, Harding RL, Longacre JJ, Snodgrasse RM. A classification of cleft lip and palate. Plast Reconst Surg 1962;29:31-9.

3. Oldfield M. Some observations on the cause and treatment of hare-lip and cleft palate based on the treatment of 1,041 patients. Br J Surg 1959;46:311-21.

4. Stark RB. Pathogenesis of hare-lip and cleft palate. Plast Reconst Surg 1954;13:20-39.

5. Fogh-Andersen P. Inheritance of hare-lip and cleft palate. Copenhagen Busck. Quoted by 3. 1942.

6. Rank BK, Thomson JA. Cleft lip and palate in Tasmania. Med J Aust 1960;47:681-9.

7. Fraser GR, Calnan JS. Cleft lip and palate: Seasonal incidence, birth weight, birth rank, sex, site, associated malformations and parental age. Arch Dis Child 1961;36:420-3.

8. Woolf CM, Woolf RM, Broadbent TR. A genetic study of cleft-lip and palate in Utah. Am J Hum Genet 1963;15:209-15.

9. Keys Smith G. Cleft lip and cleft palate in Singapore. A review of 359 children and 416 operations. Aust NZJ Surg 1962;31:289.

10. MacMahon B, Mckeown T. The incidence of hare-lip and cleft palate related to birth rank and maternal age. Am J Hum Genet 1953;5:176-83.

11. Drillien $\mathrm{CM}$, et al. The causes and natural history of cleft lip and palate, $1^{\text {st }}$ ed. E and S Livingstone Ltd: Edindurgh and London; 1966.

12. Loretz W. Westmoreland WW, Richards LF. A study of cleft lip and cleft palate births in California, 1955. Am J Public Health Nations Health 1961;51:873-7. 
13. Malpas P. J Obst Gynae. Br Emp 1937;44:434

14. Murphy D. Congenital malformations. J.B Lippincott Co: Philadelphia; 1947.

15. Knox G. The family characteristics of children with clefts of lip and palate. Acta Genet (Basel) 1963;13:299.

16. Peer L, Strean LP, Walker JC Jr, Bernhard WG, Peck GC. Study of 400 pregnancies with birth of cleft lip-palate infants; protective effect of folic acid and vitamin B6 therapy. Plast Reconstr Surg 1958;22:442-9.
17. Masters FW, Bingham HG, Robinson DW. The prevention and treatment of hearing loss in the cleft palate child. Plast Reconstr Surg 1960;23:503-9.

18. Stool SE, Randall P. Unexpected ear disease in infants with cleft palates. Cleft Palate J 1967;4:99-103.

Source of Support: Nil, Conflict of Interest: None declared. 